\title{
Sickle Cell Patient and Addiction to Tramadol: Case Management in Senegal
}

\author{
Abou Sy ${ }^{1 *}\left(\mathbb{0}\right.$, Jean Augustin Diegane Tine ${ }^{2}$, Safiyah Benmansour ${ }^{1}$, Samba Oumar Mamadou ${ }^{1}$, \\ Ba Binta1, Diallo Aissatou1, Taiwo Lateef Sheikh ${ }^{3}$, Thiam Mamadou Habib1 \\ ${ }^{1}$ Department of Psychiatry, University Cheikh Anta DIOP, Dakar, Senegal \\ ${ }^{2}$ Department of Public Health, University Cheikh Anta DIOP, Dakar, Senegal \\ ${ }^{3}$ Department of Psychiatry, Ahmadu Bello University, Zaria, Nigeria \\ Email: ^abou.sy@ucad.edu.sn, ^abousypsy@yahoo.fr
}

How to cite this paper: Sy, A., Tine, J.A.D., Benmansour, S., Mamadou, S.O., Binta, B., Aissatou, D., Sheikh, T.L. and Habib, T.M. (2020) Sickle Cell Patient and Addiction to Tramadol: Case Management in Senegal. Health, 12, 99-105.

https://doi.org/10.4236/health.2020.122008

Received: January 4, 2020

Accepted: February 7, 2020

Published: February 10, 2020

Copyright (c) 2020 by author(s) and Scientific Research Publishing Inc. This work is licensed under the Creative Commons Attribution International License (CC BY 4.0).

http://creativecommons.org/licenses/by/4.0/

\begin{abstract}
Introduction: Tramadol ${ }^{*}$ is a synthetic opioid agonist used as an analgesic. Despite its minor potential of addiction, it created recently a lot of concern. Its misuse may be motivated by a need to control the pain or by looking for her euphoric character. The aim of our study was to proceed a psychopathological reading of a case of addiction to Tramadol in a sickle cell patient with histrionic personality traits. Methods: We report the case's management of a patient with addiction to Tramadol in a sickle cell patient with histrionic personality traits. The diagnosis was based on the DSM IV criteria. The review was done in the model of semi-structured interviews. Observation: Miss DP is 23 years old, sickle cell patient (AS profile). It is addressed to us for the management of an excessive consumption of Tramadol ${ }^{\star}$ started 4 years ago. Because of the difficulties of care in outpatient, we conducted hospitalization. The interviews highlight the histrionic personality traits and disruption of family dynamics. Discussion: Painful chronic diseases require a long analgesic treatment. It is a factor of dependence specially when the patient has a personality disorder. Multidisciplinary treatment between psychiatrist and addiction specialist and medical doctor is a guarantee of success.
\end{abstract}

\section{Keywords}

Comorbidity, Derived Opiate, Withdrawal, Chronic Pain, Histrionic

\section{Introduction}

Since the delisting of Dextropropoxyphene in 2011, Tramadol has been widely prescribed despite its addictive power [1]. The relative ease of its initial prescription often contrasts with the difficulties of stopping its consumption. This situa- 
tion has led to the emergence of tramadol traffic in West Africa [2]. The analgesic properties of tramadol make it attractive for chronic painful conditions such as sickle cell disease [3] [4]. The latter is a genetic disease with autosomal recessive inheritance. It is related to an abnormal structure of haemoglobin. In Senegal, it is found in $8 \%$ to $10 \%$ of the general population [5]. Clinically, it combines chronic haemolytic anaemia, vaso-occlusive attacks and extreme susceptibility to infection. The intensity of chronic pain and their resistance to level I analgesics often leads to the prescription of opiate derivatives [3] [6]. Very often the meeting of the level II antalgic power and the euphoric properties of Tramadol on a particular ground constitute the bed of an addictive behaviour [7]. Our work was aimed at a psychopathological and clinical examination of the entanglement of a histrionic personality, a sickle cell disease and a dependence on tramadol ${ }^{\star}$. Miss DP is 23 years old, sickle cell patient (AS profile). She is addressed to us for the management of an excessive consumption of Tramadol ${ }^{*}$ started 4 years ago. Because of the difficulties of care in outpatient, we conducted hospitalization.

\section{Methodology}

We report the case of a 23-year-old patient whom we nicknamed Miss DP. She is followed at the Integrated Addictions Management Centre of Dakar (CEPIAD) for comorbid addiction to Tramadol ${ }^{\star}$ with sickle cell disease and a histrionic personality. The semi-directive interviews are made according to the model of the examination in psychiatry according to Guelfi [8]. During an individual interview, we explored the various aspects of the patient's psychic functioning. This allows us to collect information on the problems encountered by the patient. we also noted the elements of life as well as its environment. We helped the patient present her difficulties in the way that suited her. She could emphasize what seemed essential to her. It is important to show the patient that their views and concerns are respected. The diagnosis of dependence is made on the basis of the DSM V criteria. The management consisted of a demand analysis, motivational interviews and drug therapy [9]. The patient is first followed outpatient and then in hospital because of the difficulties of managing the withdrawal syndrome. We took the patient verbal consent after information.

\section{Clinical Observation}

Miss DP is 23 years old, single, nulliparous and unprofessional. She has been followed since the age of 12 for sickle cell disease (AS profile). She is hospitalized three times for chronic and diffuse pain. She is referred to us, by her doctor, for the management of an excessive consumption of Tramadol*. Miss DP started taking Tramadol ${ }^{*}$ at the age of 19 . She reported that she received an injection of Tramadol ${ }^{*}$ in the emergency room, where she was admitted for a sickle cell crisis. She told us "because of the instant analgesic action and the euphoric effect of the product I managed to know his name." Afterwards, she often went back to 
the hospital for sickle cell crises. Once there, she asked for her injection of Tramadol$^{*}$. She said that her pains stopped only when she was given this medicine. This is how the hospital's caregivers began to suspect her of abuse. They began to refuse him the injection of tramadol ${ }^{*}$. That's how she decided to get it herself.

During the first year, the patient self-injected intravenously, a $100 \mathrm{mg}$ ampoule per day. According to the patient, with time, this dose had no effect. This is how she began to increase the amount and frequency of her consumption to reach $400 \mathrm{mg}$ daily. During the fourth year, the patient increased to $800 \mathrm{mg}$ per day. She explained it by saying "the initial doses were not enough for me to achieve the desired well-being, and did not cover the whole day."

The occurrence of withdrawal symptoms led Miss DP to complain of severe pain in order to be taken to the emergency department. Thus, her parents took her from one hospital to another, where she asked for a prescription for trama$\mathrm{dol}^{*}$. In the absence of a prescription and against medical advice, she obtained the product directly in a pharmacy. When her parents decided not to give her money to buy the medicine, she asked neighbours and elderly men in the neighbourhood, without compensation, according to her. In addition, this excessive consumption ended up having consequences in her schooling, which she stopped. The patient tried weaning several times, but craving, feeling of fatigue, palpitations and tremors led to a relapse.

At admission, the psychiatric examination revealed histrionic personality traits. We also found the existence of somatoform crises occurring as a result of family conflicts, as well as insomnia. The physical examination found scars of injections in the form of "popscars", characteristic of the intake of injectable toxins. The pre-therapeutic biological examination came back without particularity. The diagnosis of severe opioid dependence with continued use of Tramadol $^{*}$ is made according to DSM V criteria.

Initially, an outpatient follow-up is proposed, with motivational interviews, which allowed evaluating and reinforcing his motivation to stop the substance. During this period, the patient gradually decreased the doses. Finally, the indication of a hospitalization arose because of the importance of somatic complaints, disturbances of family dynamics and the continuation of injections. The drug treatment included Diazepam $10 \mathrm{mg}$ injection one ampoule twice daily in 5\% slow-acting glucose, Alprazolam tablet $1 \mathrm{mg}$ morning and evening, Paracetamol $1 \mathrm{~g}$ tablet fourth times daily and Floxapen $500 \mathrm{mg}$ capsule three times daily. The infusions of Diazepam are stopped on the fourth day of hospitalization, replaced by Cyamémazine $100 \mathrm{mg}$, half a tablet morning and evening. The surveillance elements were mainly, craving, insomnia, pain, as well as other signs of withdrawal.

The hospitalization lasted 14 days. The evolution is marked by the occurrence of a somatoform crisis when stopping the infusion of Diazepam. The patient clearly expressed the desire to keep this substance injectable. Psychological interviews and psycho-education allowed us to go beyond this phase. After hospitalization, consultations are held in very short intervals. These meetings were an 
opportunity to discuss with the patient her abstinence difficulties and her desire to consume. This also allowed us to carry out family mediation. Similarly, a link between the psychiatrist, the addictologist and the physician is set up for monitoring. Evolution is marked by maintenance of abstinence.

\section{Discussion}

The occurrence of the first sickle cell crisis is the meeting point of our patient with vaso-occlusive pain. It was most often diffuse pain, moderate to severe intensity and resistant to conventional analgesics punctuating the life of Miss DP. It followed a constant anticipatory anxiety of these pains. Thus, the discovery of injectable tramadol, which calmed the pain instantaneously, during a hospitalization, favoured the alliance between Miss DP and the product. Thus, she discovered a way to calm the pain. She told us "when I was injected the product, the pain disappeared instantly. So, I managed to know the name of the drug". The intake of tramadol ${ }^{\star}$ went through two phases. The first allowed him to discover the analgesic action of the product during his hospitalization. However, it quickly went to large doses. It went from $100 \mathrm{mg}$ to $800 \mathrm{mg}$, exceeding the toxic dose of $600 \mathrm{mg}$ according to the recommendations [1]. This can be related to the phenomena of tolerance and addiction found in dependence. This classic pattern is the installation of an addictive behaviour [7]. To this we must emphasize two important elements. On one hand, the role of the caregiver, whose only objective is to calm the pain. On the other hand, the lack of information on the addictive power of tramadol* both non-specialist doctors and patients. Indeed, for the patient and her family, Tramadol* could not be considered as a drug. Moreover, this explained the tolerance of this growing consumption. Miss DP and her parents said it was a medicine, not a drug. For them, it was difficult to distinguish the addictive power of the product and its legal or illegal nature. In Senegal, drugs are treated as illicit products.

Another fundamental element is the discovery of the euphoric properties of tramadol ${ }^{*}$ in addition to its antalgic power. The coexistence of these two effects should raise the need for a good indication accompanied by psycho-education when tramadol ${ }^{*}$ is introduced. Indeed, it is often difficult to determine the limit between an opioid demand for pain and a request based on the appetite for that product. According to some authors, the management of chronic pain in sickle cell patients by opiate derivatives must begin with a careful examination [10].

This should assess the patient's suffering and motivations of analgesic request. This could help classify patients into two groups. The patient with "pain-related symptoms" whose demand is associated with pain. This behaviour disappears with the relief of pain. Its management is dependent on the behaviour of the medical staff when faced with the patient's requests for analgesia [10]. Moreover, the patients with "non-pain-related symptoms" whose demand is not associated to pain. This behaviour occurs outside of pain. The intake of substances is justified by the search for euphoria induced by opioids. These signs are in favour of 
addictive behaviour [10]. In this case, we believe that the use of DSM V [11] diagnostic criteria can be useful. Similarly, the practitioner should use clinical judgment based on regular assessment of pain, observation of withdrawal symptoms, and consistency of clinical signs with treatment kinetics. In fact, in the case of Miss DP, the diagnostic criteria showed a state of severe dependence on Tramadol*. Besides, the excessive doses which she took and the systematic use of the venous route comforted us in our diagnosis of dependence. Another important argument is the simulation of sickle cell crises in order to obtain Tramadol*. Miss DP knew how to differentiate between true and false sickle cell crises. It is in this context that it is interesting to question the impact of the histrionic personality on the misuse of opioid derivatives.

Miss DP's examination revealed histrionic personality traits such as manipulation, suggestibility, eroticization of relationships and frustration intolerance. These personality traits have facilitated the acquisition of the product and increase its consumption. In this regard, his father told us that he took her to a village more than $300 \mathrm{~km}$ from Dakar to wean her.

Despite all the constraints, Miss DP was able to convince a man who brought her injections, using seduction and manipulation. It was the same, when her father refused to give her money to buy her doses; she borrowed money from her neighbours who did not suspect anything. When they discovered her game, she started asking alms. It must be emphasized that this climbing behaviour promotes social disintegration. One of the major risks is the temptation to exchange sexual services for money. In our patient, all these strategies put in place in the context of addictive behaviour were aimed at fighting against craving. The latter when not considered may be a factor of therapeutic failure.

During treatment, it is important to put in place a well-codified framework. As such, it is important to emphasize the importance of setting realistic goals in advance with the patient [12]. This avoids a disagreement in the middle of the care, which constitutes a factor of therapeutic failure. So, our first goal was to avoid Tramadol* injections.

It should be noted that the procedures for stopping opioids are not clearly codified; they may differ according to the practitioners and the individual particularities of the patient [13] [14]. But it must integrate the assessment of the patient's motivation to stop and that of psychiatric or somatic comorbidities [12]. It is essential to take care of them at the same time during weaning.

Sometimes, the somatic complaint can be the starting point of care. Such was the case with Miss DP. Inflammation and recurrent abscesses at injection sites made injections difficult. So the initial request was the management of abscesses. At our first interview, she was in the pre-contemplation stage [9]. She could not put a direct link between taking Tramadol ${ }^{\star}$ and abscesses. An analysis of the demand and the motivational interviews allowed him to establish the causality. Since then, Miss DP has decided to stop taking Tramadol* by injection. This already significantly reduced the risks associated with the injection of Tramadol*.

From the point of view of drug therapy, it should be remembered that opioid 
substitution therapy (OST) with Buprenorphine* or Methadone* is not formally indicated. Its use is justified especially in cases where weaning is difficult [7] [13] [14]. Indeed, OST provide more comfortable care. As such, it is important to remember that the presence of significant withdrawal symptoms is generally a criterion for the introduction of opioid substitution drugs [15]. However, in our countries with few resources, other methods must be proposed as first-line. It may be the gradual decline of the opioid agonist, ketamines, and opiate rotation. even though Senegal has implemented a methadone program in recent years. We agreed, with the informed consent of Miss DP, to avoid methadone.

During hospitalization, oral non-opioid analgesics are used as first-line therapy. This allowed us to change the consumption habits, and reduce the septic risks related to the injectable route. The difficulties of this method consisted of the necessity of a medical surveillance to watch for the signs of weaning, and the risks of relapse. Whatever the chosen analgesic treatment, it is recommended to monitor its administration and to give effective doses in a systematic way rather than on demand [10]. This allows a constant relief of the patient's symptoms and deconditions the drug intake at the reappearance of the pains. The advantage of this method is also to avoid the installation of situations of permanent negotiation between the patient and the caregiver. This approach is particularly interesting in our patient because of the histrionic personality traits.

Management is not just about medication. Psycho-education occupies a place of choice. It is useful to inform the patient of the names and active ingredients of the various opioids on the market to prevent relapses. Individual psychological interviews or groups associated with social care can improve the prognosis [15]. In this context, support for competence development and self-esteem helps to strengthen resilience [16]. To achieve it we must rely on resources rather than on the problem. This allows the patient to direct all the energy deployed in his dependence to the benefit of skills aimed at better social integration.

\section{Conclusion}

Painful chronic diseases require long-term analgesic treatment. This can often lead to a situation of dependence, especially in patients with psychiatric comorbidity. In such cases, joint care between the psychiatrist, the addictologist and the physician is a guarantee of success.

\section{Conflicts of Interest}

The authors declare no conflicts of interest regarding the publication of this paper.

\section{References}

[1] Cassier, V. (2014) Etude retrospective des intoxications aiguês au tramadol (2007-2013) À partir des données du centre antipoison et de toxicovigilance de Bordeaux: Impact du retrait du dextropropoxyphène. Thèse pour l'obtention du Diplôme d'état de docteur en pharmacie Présentée et soutenue publiquement Le 7 
mai 2014 .

[2] Maiga, D.D., Seyni, H., Moussa, A.O. and Sidikou, A. (2012) Mesusage du tramadol par les adolescents et jeunes adultes en situation de rue. The Pan African Medical Journal, 13, 55.

[3] Chèze, M. (2016) Opiacés, opioïdes et produits de substitution: Toxicologie. EMC-Biologie Médicale, 11, 1-13.

[4] Organisation mondiale de la Sante (OMS) (2003) Comite OMS d'experts de la pharmacodépendance. http://libdoc.who.int/trs/WHO TRS 915 fre.pdf

[5] Thiam, L., Drame, A., Coly, I.Z., Diouf, F.N., Seck, N., Boiro, D., Ndongo, A.A., Basse, I., Niang, B., Deme/Ly, I., Sylla, A., Diagne, I. and Ndiaye, O. (2017) Profils epidemiologiques, cliniques et hematologiques de la drepanocytose homozygote SS en phase inter critique chez l'enfant a Ziguinchor, Senegal. Pan African Medical Journal, 28, 208. https://doi.org/10.11604/pamj.2017.28.208.14006

[6] Vuillet-A-Ciles, H., Buxeraud, J. and Nouaille, Y. (2013) Les médicaments de la douleur: Les antalgiques de palier II. Actualités pharmaceutiques, 52, 27-30. https://doi.org/10.1016/j.actpha.2013.03.016

[7] Lanier, R.K., Lofwall, M.R., Mintzer, M.Z., Bigelow, G.E. and Strain, E.C. (2010) Physical Dependence Potential of Daily Tramadol Dosing in Humans. Psychopharmacology, 211, 457-466. https://doi.org/10.1007/s00213-010-1919-3

[8] Daniel Guelfi, J. (2007) Frederic Rouillon l'examen clinique. In: Julien Daniel Guelfi, Frederic Rouillon Manuel de Psychiatrie, Elsevier Masson, Paris, 101-105

[9] Prochaska, J.O. and DiClemente, C.C. (1983) Stages and Processes of Self-Change of Smoking: Toward an Integrative Model of Change. Journal of Consulting and Clinical Psychology, 51, 390-395. https://doi.org/10.1037/0022-006X.51.3.390

[10] Lusher, J., Elander, J., Bevan, D., Telfer, P. and Burton, B. (2006) Analgesic Addiction and Pseudo Addiction in Painful Chronic Illness. The Clinical Journal of Pain, 22, 316-324. https://doi.org/10.1097/01.ajp.0000176360.94644.41

[11] American Psychiatric Association (2015) Manuel diagnostique et statistique des troubles mentaux DSM V. Elsevier Masson, Paris, 1200.

[12] Apert, B., Benzerouk, F. and Rigaud, A. (2015) Trouble de l'usage du Tramadol chez un jeune adulte. Alcoologie Et Addictologie, 37, 327-332.

[13] Cupples, N. and Moore, T.A. (2013) A Case of Tramadol Dependence and Successful Treatment with Buprenorphine/Naloxone. Mental Health Clinician, 3, 283-285. https://doi.org/10.9740/mhc.n183348

[14] Prakash, J. and Saini, R. (2010) Tramadol Dependence: A Case Report. Medical Journal Armed Forces India, 66, 93-94. https://doi.org/10.1016/S0377-1237(10)80114-5

[15] Haute autorité de la santé (2004) Stratégies thérapeutiques pour les personnes dépendantes des opiacés. Place des traitements de substitution, conférence de consensus, 23 et 24 juin 2004 .

[16] Bruno, D. (2003) Facteurs de résilience dans les toxico-dépendances. Psychotropes, 9, 61-75. https://doi.org/10.3917/psyt.091.0061 